\title{
MULTICULTURAL EDUCATION AND HUMANISM THEORY AS AN EFFORT TO IMPROVE THE SOCIAL SENSIBILITY OF PRIMARY SCHOOL STUDENTS
}

\author{
Pipiet Alifah \\ State University of Jakarta \\ Pipietyalifah@gmail.com
}

\begin{abstract}
Data from the Indonesian Child Protection Commission noted that 34\% Children deal with the law, one of the cases is bully. The bully case is one proof of the social sensitivity of the elementary students. The program for basic education that can be pursued to increase social sensitivity is through multicultural education and the theory of humanism. This study uses a literature study method that collects several reference journals and textbooks. The results of the research are collaborative methods of multicultural-based education and humanism theory when classroom learning is more effective for improving social sensitivity for elementary school students.
\end{abstract}

Keywords: Social sensitivity, education, multicultural, humanism, elementary school

\begin{abstract}
Abstrak. Data dari Komisi Perlindungan Anak Indonesia mencatat bahwa 34\% Anak-anak berurusan dengan hukum, salah satu kasusnya adalah bully (mengejek). Kasus mengejek adalah salah satu bukti kepekaan sosial siswa SD. Program untuk pendidikan dasar yang dapat diupayakan untuk meningkatkan kepekaan sosial adalah melalui pendidikan multikultural dan teori humanisme. Penelitian ini menggunakan metode studi pustaka yang mengumpulkan beberapa jurnal referensi dan buku teks. Hasil penelitian adalah metode kolaboratif pendidikan berbasis multikultural dan teori humanisme dalam pembelajaran kelas lebih efektif untuk meningkatkan kepekaan sosial bagi siswa sekolah dasar.
\end{abstract}

Kata Kunci: Sensitivitas sosial, pendidikan, multikultural, humanisme, sekolah dasar

\section{Introduction}

The embryo of individual character determination begins early, since the school at elementary level that is elementary school children is introduced how to speak and behave politely. The way these children acquired through formal education and informal education. Although the role of parents in educating children has a huge role, the role of formal schools is also very important in fostering the behavior of children. If in formal education then known the term students to call children. The formal school appointed in this discussion is the Elementary School, the elementary school students will mingle and socialize with their peers.
In the socialization process is required social sensitivity attitude among students. social sensitivity can be interpreted as a form of concern among fellow students, have a sense of belonging, and can tolerate in communicating. The fact that should be aligned in the socializing activities of children seemed to fade for children domiciled in cities in Indonesia, the nature of individualism is more dominant. Indeed, there is a point if humans are individual beings as well as social beings, only with increasingly sophisticated technology so that the rapidly growing digital era in Indonesia does not make students to be able to socialize in accordance with the development of its age directly. Social 
sensitivity can be felt if children interact directly with their social environment.

One example of a large city that the author observes is Jakarta. In the city of Jakarta elementary students are quite diverse from some cultural background of parents who come from several regions in all regions of the country of Indonesia. This form of multiculturalism has an effect on different behavior when responding to a problem.

Data from the Indonesian Child Protection Commission noted that 34\%Children deal with the law, one of the cases is bully. The context of this problem, in essence as a human being, is to be tolerant of mutual tolerance despite the colorful background of everyone's culture.

Humanism theory, which means humanizing human being is one theory that can underlies the formation of social sensitivity. This will be another challenge for teachers who teach in urban areas, especially Jakarta. So that students can socialize with peers without having to leave one of the Indonesian cultural identity is "caring", based on research from various sources of journals and book sources that mentions that multicultural education and humanistic theory can be one solution of the problem of social sensitivity of students SD then the discussion of this paper is "Multidimensional Education and Humanism Theory: Efforts to Improve Social Sensibility of Elementary School Students."

\section{Method}

The type of this research is qualitative research with literature study method. According to Sukardi (2017) literature study conducted by each researcher with the main objective is to find the foundation of foundation or foundation to acquire and build the theoretical base, the frame of thinking, and determine the suspicion of temporary or often referred to as research hypothesis, so that researchers can understand, locate, organize, and then use the library variation in the field. By conducting literature studies, researchers have a deeper and deeper understanding of the issues to be studied. Various sources of literature that can be used by researchers are journals, research reports, scientific magazines, newspapers, relevant books, seminar results, unpublished scientific articles, sources, letters - letters, and others.

\section{Result and Discussion}

\section{Implementation of Multicultural Education in Primary Schools}

Indonesia is a nation of diverse tribes, cultures, religions, and races. The diversity makes Indonesia rich with culture. The religion can also be called multiculturalism. Differences that want to be unity, does not mean that with the diversity makes Indonesia split. However, with the diversity it will happen the process of learning other things that can be the same is owned by certain groups, from the learning process occurs the process of cultural diffusion that increasingly makes Indonesia rich through the potential possessed by each individual.

Based on John (Banks, 2010) multicultural education is education that values diversity and includes the perspectives of a variety of cultural groups on a regular basis. Its proponents believe that children of color should be empowered and that multicultural education benefits all students. Based on John (Bennett, 2011) an important goal of multicultural education is equal educational opportunity for all students, with result of closing the gap in academic achievement between mainstream students and students from underrepresented groups.

The occurrence of multicultural education is a transmigration process. The process of transmigration has brought changes in many aspects, in the educational aspect of the impact is quite influential on the behavior of students in interacting in the social environment. In the opinion of Sofan (2013), "education has a purpose to make children happy to get education and can socialize well in society." Therefore, the role of multicultural education plays a role in diversity that helps students to 
be accepted, acknowledged, and comfortable around.

As for how to implement multicultural education in elementary school listed in the research (Maulani, 2012) that is through the role of some of the following aspects: 1 . The Role of Teachers and Schools in Developing Religious Schools The role of teachers in this case includes; first, a teacher / lecturer should be able to be democratic. 2. Development of Multicultural Based Religious Education Material In order to build inclusive religious school there are some religious education materials that can be developed with multicultural feel.

In the journal on multicultural education in Finland mentioned that the discourse on multicultural education and the concept of intercultural competence in the European and Nordic countries in Finland. (Fred, Dkk: 2012) said to address the discourse on multicultural education is then focused on the decision makers, researchers, and also student teachers. In this way, the article is an attempt to evaluate how intercultural competencies can and should be conceptualized in today's global scholarship.

The national core curriculum for basic education (Finnish National Education Council / FNBE, 2004) there are several different goals for the majority (ethnic) and (ethnic) minorities. The focus of the research is to embrace cultural acculturation or social processes that integrate the elements of minority culture into the majority to create a new culture without eliminating the original elements. Based on the research can be used as a reference for elementary school teachers in Indonesia in teaching students who have diversity in the classroom, the process of cultural integration can be one of the solutions for students in communicating so that social sensitivities arise among students.

\section{The Role of Humanism Theory in Elementary Learning}

According Nur'aini (A. Malik, 2005:

181) said that "education is a process of humanization or in other words the process of humanizing human beings. Education, then, is a process, an endeavor, an effort to provide students with a strong foundation for humanizing human beings. "

In the theory of humanistic psychology, Maslow assumes that human beings are actually good creatures, so that humans have the right to realize their true self in order to achieve self-actualization. In the process of realization of identity is needed recognition from the community, but often humans are hampered by the circumstances of society that is not in line even the rejection of the talent and interest so that there is a social imbalance. Minderop (Krech, 2011: 48)

In the journal written by (NurHikma, 2015: 1) obtained the results of research on the analysis of novel shoes dahlan which shows that there are attitudes that can be a role model that the children can grow into a more mature, strong, independent, when face problems. The problem with Dahlan's figure is about the economic limitations, that everyone who can enjoy the process in the limitations and have a good work ethic attitude then the process of self-actualization can be achieved.

Based on the description of the journal's example of the novel analysis, it can be attributed to elementary students' learning but the type of material given will be slightly different. For example, for stages of elementary school age children teachers can introduce to novel students KKPK or SmallSmall Punya Karya. In the novel review which contains several sub chapters and different stories each series and novel is the work of elementary school students who have the talent to write. It can be an example of loving attitudes of friends, doing good to both parents, as well as many other positive stories that can be an example for students. so that, in accordance with the theory of humanistic learning that can make students can develop self-actualization.

Research by (Halloluwa, 2014) Sri Lanka is a country with a high standard of 
education. Literacy rate reached $91.2 \%$ with a ratio of 1:20 ratio which means 1 teacher to teach students as many as 20 people. Based on the ratio, there is an imbalance that happens is the unevenness of the number of teachers teaching in rural areas, when the observation dikedasaan and urban impact on decreased teacher qualifications and decreased quality of education in downtown Colomba. Based on these research journals it is necessary for humanist social sensitivity to periodically exchange roles of teachers coming from the city to communicate with teachers in rural Colomba. Proving that the practice of the theory of humanism is needed on aspects of education that are not only limited to students but the role of teachers so that student actualization can be realized.

Research results show that: (1) model development begins with a preliminary study, development study, and implementation which then produces a model of humanist learning in character education in SD, (2) humanistic model religious character in elementary school education demonstrates a good level of execution, meets criteria very effectively, very practically and validly based on a rational thought base with strong and relevant supporting theories, (3) a model of religious humanist learning in character education that is effectively developed for use in character education in primary schools, and (4) learners have a very positive response to the model of religious humanist learning in character education in elementary schools."

In accordance with the philosophical views associated with religion, the human soul will not be dry if in life has the guidelines that regulate his relationship with God. It has been proved that the humanist theory that juxtaposed with the emphasis that has been developed in the elementary school learning resulted in a positive response in elementary students

\section{Efforts to Increase Social Sensitivity of Elementary School Students}

Literally sensitivity comes from a sensitive word that means easy to feel or easily aroused or a condition that easily reacts. Social sensitivity will elicit students' reactions in seeing the social phenomena around their own students, in addition it is expected to appear active or action as a follow-up to a reaction that leads to a positive thing. (Kiky, 2015: 265-266)

The emergence of the term moral degradation is not just a term, but a problem to be solved together. The role of teachers, parents, and the environment becomes the atmosphere for character formation of elementary students. They can see, observe, imitate the behavior of those around them. As adults, it is expected to be able to influence the positive behavior on elementary school students for social sensitivity to be formed early on. Good impression and a solid initial foundation can determine the power of good behavior by elementary students.

Many efforts have been done by the government and implemented by elementary school teachers through character education. In a learning process that involves character, students' emotions are guided to be a polite person so as to produce balanced psychomotor, affective, and cognitive aspects. The good synergy is the initial capital of students to become complete human beings who can actualize themselves through the theory of humanism.

The difference lies not in the difference, but the color that blends in the difference. So that the term multicultural education that can integrate the elements of culture, introducing cultural diversity, and how to address the diversity that fused in the learning in the classroom. Efforts to accept differences and convince students that the diversity that brought Indonesia into a country rich in ethnicity, culture and language. Emphasizing to students there is no superior group and disempowered group if the student is in a majority group. So as not to bring up negative stereotypes that have an impact on discrimination.

Here is an example of a journal analysis written by (Kelly, 2014: 1) This study investigates cases of cyberbullying among 
students. A total of two hundred and eighty two students have attended a survey activity on students' intentions reporting cyberbullying cases. However, the cyberbullying case reporter only focuses on the victims. While students who know their friends involved in cases of cyberbullying tend to be passive.

The case of cyberbullying means that the lack of awareness of each person to have a sense of mutual love and compassion. As a result, there is a group that feels more power, more self, and the right feeling. Justification of the perception of subjectivity that causes a social gap in the community. Target cyberbullying is often the case in adolescents who have a tendency of active users of social media. Millennial generations seem to be spoiled by the power of digital that should be more wise in using social media.

The existence of these journals is evidence that the need for preventive and supervisory measures for elementary students in particular khususus using the internet. In order for cyberbullying cases do not penetrate the joints of students' thinking elementary school teachers can perform various actions.

In the study (Annisa, 2016) School programs to prevent and deal with bullying in MuhammadiyahMlangi Elementary School have not been determined in detail. The first action taken is to advise the perpetrators of verbal bullying cases. If the student is still repeating the bullying act then the class teacher, Bk teacher, and guardian of students discuss to solve the problem. The characteristics of students who have social sensitivity in the environment are those who are able to have social sensitivity so that it can determine the right step if there is a social problem around it. Such social sensitivity is gained through the social insights gained from schools, the playing environment, and families.

The above description has shown the aspects that affect the social sensitivity of elementary students from various sources of book references and journals, hence efforts to increase social sensitivity through multicultural education and humanism theory is that teachers can integrate the color of cultural diversity based on the background of kebudaayan parents through giving the material about bhineka single ika which automatically entered on the themes of each learning

\section{Conclusion and Suggestion}

\section{Conclusion}

Religion without science will be paralyzed whereas science without religion will blind (Albert Einstein). The phrase leads to the thought that it takes the foundation of religious thought in the process of selfactualization. When the attainment has been achieved, man no longer seeks empty space on him because the human soul has been filled with a belief that can lower the arrogance in self. The righteous and best feeling that can lead to negative stereotypes that can lead to discrimination processes will not happen.

The melting of primordialism can be through multicultural education and humanistic learning theory that can prepare the superior generation of elementary school. The two things are put together and then packed into the practice of learning in elementary school. The younger generation is the successor of the ideals and as the hope of the older generation. Therefore, the development of learning based on the character so that students can be trained and educated mentally from childhood in the hope of improving the quality of morality in Indonesia, so that people no longer hear the term moral degradation that occurs in Indonesia's young generation. If the mentality of social sensitivity is established to be solid from the beginning then the hope for the next generation that is still 7-13 years old (elementary school aged), five to ten years to come will be a dignified generation.

\section{Suggestion}

To face the global challenge it is necessary to have a character that has a good mentality in communicating in the global 
environment. Such procedures need to be established since elementary school-aged children to have a recurring habit of social sensitivity. Parental guidance is needed to support children socialize globally to meet with friends of different tribes, religions, or races so that tolerance appears naturally in children. The role of teachers is important in formal education, both the bad character of students is also influenced by the teaching of teachers. Therefore, it is necessary to recognize the diversity of Indonesian culture and how to overcome such diversity, for example through multicultural education.

\section{REFERENCES}

Ahmad, Nur'aini. (2017). Pendidikan Islam HumanisKajianPemikiran A. Malik Fadjar. Tangerang Selatan: Onglam Books

Amri, Sofan. (2013). Pengembangandan modelpembelajarandalamkurikulum 2013. Jakarta: PT PustakaPubliser.

Annisa. (2016). Hubungan Jenis Kelamin dengan Perilaku Bullying pada Anak Usia Sekolah di SD Muhammadiyah Mlangi Gamping Sleman Yogyakarta. Skripsi. Universitas 'Aisyiyah Yogyakarta, Yogyakarta.

Chandra, Kiky. (2015). "Penerapan Model Pembelajaran Inkuiri Terbimbing untuk Meningkatkan Kepekaan Sosial Siswa dalam Pembelajaran IPS diMTs NegeriLamongan." dalamJurnalAkademia, vol. 9, no. 2, hlm. 265-266.

Fred, D. M., Paatela, N., Kaisa K., et al. (2012). Multicultural Education in Finland: Renewed Intercultural Competencies to the Rescue?.International Journal of Multicultural Education. Vol. 14, No. 3, 1-13.

Halloluwa. (2014). Stimulating Learners' Motivation in Primary Education in Sri Lanka - A Literature Review. iJet. Volume. 9. Issue 1, 47-52.

Hikma, Nur. (2015). AspekPsikologisTokohUtamaDalam Novel Sepatu. JurnalHumanika. Vol. 3, No. 15, hlm. 1.

Jamarudin, Abdul, G., Siti., P.S. (2014). Pengembangan Model PembelajaranHumanisReligiusDalamPendidikanKarakter Di SekolahDasar. Jurnal Pembangunan Pendidikan: FondasidanAplikasi. Vol. 2, No.2. hlm.114.

Kelly W., Marilyn C., Alexandria O., et al. (2015). University students' intentions to report cyberbullying. Australian Journal of Educational \& Developmental Psychology. Vol. $15,1-12$.

Maulani, Amin. 2012. Transformasi Learning dalamPendidikanMultikulturalKeberagamaan. Jurnal Pembangunan Pendidikan: FondasidanAplikasi. Vol.1, No.1, hlm. 29.

Minderop, Albertine. (2011). Psikologi Sastra: Karya Sastra, Metode, Teori Dan ContohKasus. Jakarta. YayasanPustakaObor Indonesia.

National Core Curriculum. (2004).Finnish National Board of Education/FNBE, term basic education.

Santrock, John. W. (2011). Educational Psychology. USA: Mc Graw Hill.

Setyawan, David. (2017). KPAI Terima Aduan 26 Ribu Kasus Bully Selama 2011-2017. Berita KPAI. diaksespada 31 Januari 2017

Sukardi. (2017). Metodologi Penelitian Pendidikan Kompetensi dan Praktiknya. Jakarta: PT BumiAksara 